\title{
INTERNATIONAL AGREEMENTS WITHOUT THE ADVICE AND CONSENT OF THE SENATE.
}

The Constitution of the United States ${ }^{1}$ provides that the President "shall have power by, and with the advice and consent of the Senate, to make treaties, provided two-thirds of the Senators present concur." Judge Story, in his work on the Constitution in commenting on this passage, says: "The power to make treaties is by the Constitution general, and, of course, it embraces all sorts of treaties for peace or war; for commerce or territory; for alliance or succors; for indemnity for injuries or payment of debts; for the recognition and enforcement of principles of public law, and for any other purposes which the policy or interests of independent sovereigns may dictate in their intercourse with each other."2

From this it might be supposed that an agreement with a foreign state, to which the approbation of the Senate has not been given, is a thing unknown to our constitutional practice. This is, however, not the fact, and it will be the purpose of this article to point out.that there are certain classes of international agreements, in the making of which the Senate does not have a share.

I.

Before passing to an examination of the several classes it should be noted that the Constitution recognizes ${ }^{1}$ certain international agreements which are not treaties. ${ }^{2}$ While the states are forbidden to enter into "any treaty, alliance or confederation," they may, with the consent of Congress, make agreements and compacts with each other or with foreign powers. ${ }^{3}$

The Articles of,Confederation forbade the states, without the consent of Congress, to " enter into any conference, agreement, alliance or treaty with any king, prince or state," or, without the same assent, "to enter into any treaty, confederation or alliance" with each other." The omission of "agreement" from the second list was apparently construed by certain states to permit

I. Constitution Art. II, Sec. 2.

2. Commentaries on the Constitution $\S \times 508$.

3. Constitution. Art. I, Sec ro, cl. I and 3.

4. Articles of Confederation, Art. VI, Secs, I and 2. 
agreements between members of the confederation. Thus, Virginia and North Carolina, in 5779 , and Pennsylvania and Virginia, in 1784 , made agreements with reference to their common boundaries. In 1783 , Pennsylvania and New Jersey came to an agreement as to the jurisdiction of the two states over the river Delaware and its islands. New York and Massachusetts, in 1786 made an agreement for the surrender by the latter of its land claims in Western New York. 5 In 1785, Maryland and Virginia entered into a compact respecting navigation and jurisdiction in Chesapeake bay, Pocomoke sound and the Potomac river, and also as to port regulations and fisheries in these waters. It was expressly held by the Supreme Court, in Wharton v. Wise, that the last mentioned agreement was not a " treaty, alliance or confederation" within the meaning of Article VI, paragraph 2, of the Articles of Confederation. ${ }^{6}$ It should also be noted that the Articles of Confederation provided that "differences" between two or more states concerning boundaries, jurisdiction, or any other cause whatever," might, on petition to Congress by one of the parties, be referred for settlement to a commission to be established under the direction of Congress, and that the decision thereof should be final. ${ }^{7}$ Reference to Congress was, therefore, optional, and the provision manifestly contemplated an attempted settlement by the states involved before appeal was made to Congress.

The practice in this matter under the confederation ${ }^{8}$ evidently lead the framers of the Constitution to prohibit agreements or compacts, except with the consent of Congress. Since the adoption of the Constitution, numerous agreements or compacts, relating principally to boundaries, have been made between states, but all, so far as known, with Congressional assent.

Judge Story, writing in 1833 , considered that the precise distinction between the words, "treaty," "agreement," and." compact" was not clear. He seemed inclined, however, to assign to the first term engagements of a political character. The other two, he thought, might apply to "what might be deemed mere private rights of sovereignty, such as questions of boundary, in-

5. Gannett, Botundaries of the United States, 97, 86, 83, 84, 69. Poole v. Fleeger, 1x Pet. 185 .

6. Wharton v. Wise, 153 U. S, 163.

7. Articles of Confederation, Art. IX, Sec. 2.

8. Madison in his " Notes on Proceeding of the Federal Convention," referred to the above agreements between Virginia and Maryland and Pennsylvania and New Jersey as " compacts without previous application or subsequent apology." Doc. Hist. of the Const. III, $x_{55}$. 
terests in land, situated in the territory of each other, and other internal regulations for the mutual comfort and convenience of states, bordering on each other." 9

The meaning of the words "treaty," "agreement" and "compact," as applied in international relations was discussed by Chief Justice Taney in the case of Holmes $v$. Jennison, in the year r840.10 The question here involved was the right of a state (Vermont) to surrender a fugitive from justice, on the request of a foreign government (lower Canada), and it was there held that the surrender might not lawfully be made, because it necessarily involved an agreement between a state and a foreign power to which the assent of Congress had not been given. In considering the meaning of the words "treaty," "agreement" and "compact" as used in Article I, Section ro of the Constitution, Chief Justice Taney observed that ' the words 'agreement' and 'compact' cannot be construed as synonymous with one another, and still less can either of them be held to mean the same thing with the word 'treaty,' in the preceding clause." . . . "Undoubtedly in the sense in which the word is generally used, there is no treaty (here) between Vermont and Canada. For when we speak of a 'treaty we mean an instrument written and executed with the formalities customary among nations; and as no clause in the Constitution ought to be interpreted differently from the usual and fair import of the words used, if the decision of this case depended upon the word above mentioned, we should not be prepared to say that there was any express prohibition of the power exercised by the state of Vermont." He then proceeds to quote the definition of these words as given by Vattal who says: "A treaty, in Latin foedus, is a compact made with a view to the public welfare, by the superior power, either for perpetuity or for a considerable time."

"The compacts which have temporary matters for their object, are called agreements, conventions and pactions. They are accomplished by one single act and not by repeated acts. These compacts are perfected in their execution once for all; treaties receive a successive execution whose duration equals that of the treaty. 11

It is true that Vattel's definition of agreements, quoted by Jurge Taney, speaks of them as "accomplished by one single act

Story on the Constitution $\$ \S \times 402$, 1403 .

ro. Holmes v. Jennison, $\mathrm{I}_{4}$ Pet. 540.

I1. Ibid $57 x, 572,573$, and Vattel, Law of Nations, II $\$ \S ~ 152,153$. 
and not by a series of acts . . . perfected in their execution once for all." The reference here is said to be to so-called "transitory conventions," "transitory," because by their nature they are at once executed and leave nothing more to be done. As Vattel says elsewhere, 12 of agreements of this kind, "if they are valid, they have in their own nature a perpetual and irrevocable effect." Such, according to Wheaton, are treaties of cession, boundary or exchange of territory, which are not abrogated like other treaties on the breaking out of war between the contracting parties. 13 Nevertheless, it may be doubted whether the framers of the Constitution used the words agreement and compact, either in the restricted or extended sense. They had in mind the various compacts which the states, under the confederation, had made with each other, and they intended apparently to provide that if the states made agreements in the future, it must be with the assent of Congress. The language of the constitutional provision is that "no state shall, withont the consent of Congress, enter into any agreement or compact with another state or with a foreign power." (I ro, 3). There is no distinction here between agreements, domestic or foreign, and the rule of construction, noscitur a sociis, would raise the presumption of a similar meaning and limitation for both. 14 The case of Holmes $v$. Jennison is, however, authority for the proposition that extradition by a state at the request of a foreign government, necessarily involves an agreement which is one of those forbidden to the states to enter into except with the consent of Congress. It also declares obiter, that such an agreement is not a treaty. The inference, therefore, is that extradition and similar agreements, made by the states, would be lawful, if authorized by Congress.

It is believed that the only instance of agreements between a state of the Union and a foreign power (and that too, without the consent of Congress), were those growing out of the interests

12. Vattel, L2w of Nations II, ch. I2, $§$ Ig2.

13. Wheaton's International Law, pt. III, ch. 2, §§9, ro.

14. Mr. Justice Field in Virginia $v$. Tennessee, referring to agreements and compacts between the states said, that the prohibition "is directed to the formation of any combination tending to increase the political power of the States, which may encroach upon, or interfere with, the just supremacy of the United States." In delivering the opinion of the Court in Stearns v. Minne sota, Mr. Justice Brewer pointed out that a distinction exists between agreements between the States which relate merely to property rights, and agreements which have a political object, the former being permissible, the latter not. 148 U. S. at p. 5 Ig. I79 U. S. at p. 244. 
of Maine and Massachusetts in the northeastern boundary dispute with Great Britain, and relating more particularly to the so-called Aroostook War in 1839 . The dispute had then reached an acute stage and armed forces from Maine and New Brunswick had been marched into the disputed territory. A collision was averted through the mediation of General Scott, and an agreement was reached by the governors of Maine and New Brunswick, March $21-23,1839$, by which each side was ta retain possession of territory occupied by each, pending final adjustment by the American and British governments, but without prejudice to their respective rights and claims; the Maine forces to consist of a civic posse kept there to prevent timber depredations. This arrangement, in a sense, carried into effect an earlier agreement signed by Mr. Forsyth, Secretary of State, and Mr. Fox, the British Minister, on February 27, of the same year, in which an understanding was reached as to the line of conduct to be recommended to the governors of Maine and New Brunswick in dealing with the diffculty. But as the terms of the two arrangements differed, it cannot be said that the second was a fulfillment of the first. ${ }^{15}$

The interests of Maine and Massachusetts were in part provided for in Article $\mathrm{V}$ of the Webster-Ashburton treaty, wherein it was stipulated that,

"Whereas, in the course of the controversy respecting the disputed territory on the northeastern boundary, some moneys have been received by the authorities of Her Britanic Majesty's Province of New Brunswick, with the intention of preventing depredations on the forests of the said territory, which moneys were to be carried to a fund called the 'disputed Territory Fund,' the proceeds whereof it was agreed should be hereafter paid over to the parties interested in the proportions to be determined by a final settlement of boundaries: It is hereby agreed that a correct account of all receipts and payments on the said fund shall be delivered to the government of the United States within six months after the ratification of this treaty, and the proportion of the amount due thereon to the states of Maine and Massachusetts, and any bonds or securities appertaining thereto shall be paid and delivered over to the government of the United States, and the guvernment of the United States agrees to receive for the use of, and pay over to the states of Maine and Massachusetts their respective portions of said fund."

We learn from notes exchanged between Mr. Pakenham, British minister in Washington, and Mr. Buchanan, Secretary of State, on March I7 and April 21, 1847 , respectively, that agents of Maine and Massachusetts properly accredited to the governor of New Brunswick by letters from Mr. Pakenham and Mr. Buchanan proceeded to New Brunswick and there effected a settlement

15. Memoirs of General Scott, II; 347-351, 338-341. 
of the disputed territory fund account with commissioners appointed by the provincial government. The result was a "deed of agreement and settlement concluded between the agents and commissioners on both sides, and the money found to be due to the states of Maine and Massachusetts, and the bonds and securities appertaining thereto were paid over and delivered to the agents of those states."

The agents of the two states had the duty, according to the terms of the article above quoted, to agree upon "the proceeds to be paid the parties interested in the proportions" determined by the final settlement of the boundary line. This must have been principally a mathematical calculation. The resulting agreements would certainly be among those described by Vattel as "compacts perfected in their execution once for all" and accomplished by a single act." But they were evidently not thought by Mr. Buchanan and President Polk to require the constitutional assent of Congress.

It can hardly be said that the assent of the Senate to the Webster-Ashburton treaty, by recognizing the claims of Maine and Massachusetts, gave legal validity to the proceeding. The provisions of Article $V$ of the treaty contemplated that the claims should be adjusted by the government of the United States acting in behalf of the two states. Practical considerations, however, made it preferable that the real parties in interest should settle the account. The object of the above correspondence between Buchanan and Pakenham was, therefore, to establish the fact that the British government was discharged of all obligations in the matter, and Buchanan replied that the United States government so regarded it." 16

The opinion has been expressed that it is beyond the competence of a state of the Union, and a bordering province of Canada to enter into an agreement; for example, to regulate fisheries in their contiguous waters. 17 With all deference to the

I6. Ex. Doc. 63, 37 Cong. 2 sess, vol, 5.

It may be thought that this agreement is referable to the war power of the states, which is exercisible when they are "actually invaded" (Const. I, Io, 2) Webster in his speech in the Senate in defense of the Treaty of Washington said that "Something like a border war had broken out. . . . There was Fort Fairfield, Fort Kent and I know not what other fortresses, all memorable in history." "Works, vol. 5, p. 93 .

r7. Butler's Treaty Making Power I, § r23.

Although the British North American Act of 1867 vested in the Dominion Parliament exclusive legislative powers in respect to "sea coast and inland fisheries" (Sec. 9r), it appears to be modified as to the Province of Ontario by subsequent act of the Imperial Parliament (48 V. ct. 9, S. 2) which gave $t$ the Legislature of Ontario rights of legislation in respect to fisheries in tha province. Revised Statutes of Ontario (I887), I, 337 . 
learned authority, it seems that such an agreement would be lawful if sanctioned by Congress. It would, of course, be preferable that the whole matter of fishery in the bordering great lakes and rivers should be regulated by treaty, made with Great Britain in behalf of the Dominion of Canada, if the Constitution permits. In the absence of formal treaty, there is certainly no legal obstacle to an agreement of this kind.

The Supreme Court of the United States has said that the Constitution contains no grant to the Federal government of a power to regulate fisheries in the several states. 18 It must, therefore. be one of those powers, which by the tenth amendment are expressly reserved to the states. As Professor Burgess has observed, "It (the treaty-making power) is certainly limited by the general principle of the Constitution, i. e., by the constitutional distribution of the powers of government between the general government and the commonwealths. The treaty-making power cannot deal with any subject reserved by the Constitution to the exclusive jurisdiction of the commonwealths." 19

Mr. Butler, on the other hand, thinks that under Article VI of the Constitution (making treaties the supreme law of the land), the Federal government may, "go much further in regulating matters within the jurisdiction of the states than the legislative department of the government can go."20 In Manchester $v$. Massachusetts, 21 Mr. Justice Blatchford said that the state of Massachusetts necessarily had control of her fisheries in the absence of congressional legislation assuming control for the national government. But he said that as to the right of the Federal government so to do, he expressed no opinion. Whichever view is correct, the power to protect fisheries in the states, resides at present in their respective governments. Pending the settlement of the constitutional question by the Supreme Court (as must eventually be done), the bordering states of the Union may find it necessary to act in their own behalf, and make fisheries agreements with the Dominion or Provincial governments.

This would seem very plainly to be the sort of agreement contemplated by the constitutional provision here discussed. The mere subject-matter of the agreement would not make it a treaty

18. McCready v. Virgintia, 94 U. S. 39r. Lawton v. Steele, I52 U. S. I33.

Ig. Political Science Quarterly, Vol. 6, p. 343.

20. Butler op. cit. p. 32I, citing 8 Opp. Atty. Gen. 44r.

2I, I39 U. S. 240 . 
as the word is used in the Constitution. The states may make with each other boundary adjustments and cessions of territory, but these are not treaties. Neither would it be a treaty because made with a foreign colony, for the Constitution expressly provided for agreements with a foreign power. One is forced either to adopt this conclusion or to admit that, under our Constitution, the treaty-making power is divided, and that engagements with foreign states, which are political in character and interest the states as a whole, are made by the President, ordinarily with the concurrence of the Senate, and that those which are merely local and non-political may be made by the states with the consent of Congress. In any event, the arrangement becomes a national act by receiving Congressional sanction and thus avoids the danger of particularism.

In other federal system (for example, Germany and Switzerland) the component states have a limited right of making treatises with each other and with foreign states. In Germany they also have the right of sending and receiving diplomatic agents. 22 A fundamental law of the empire permits postal and telegraph treaties between the individual states and their immediate foreign neighbors. ${ }^{23}$ Actual practice has, however, been much broader. The individual states have made treaties with their immediate foreign neighbors relating to fishery and navigation in the Rhine and Lake Constance; also as to boundaries, railroads and extradition. 24 In only one instance, that of the boundary convention of April 28, 1878, between Baden and Switzerland, does there seem to have been a confirmation by the Imperial government of these arrangements. In this case the convention of June 24, I879, with Switzerland, recognized the preceding one as having legal validity for the German empire. 25

The Swiss constitution gives to the confederation the sole right of "concluding alliances and treaties with foreign powers," but " by exception the Cantons preserve the right of concluding treatises with foreign powers, respecting the administra. tion of public property, and border and police intercourse; but such treaties shall contain nothing contrary to the confedera-

22. Wilson, The State, $\S 543$.

23. Burgess, Political Science, II, I63.

24. Martens, Nouveau Recueil Generale de Trartes. 2 Serie, X, Table Generale, See names of various states and volums cited.

25. Ibid $X, 430,433$. 
tion or to the rights of other Cantons." Treaties made by the Cantons are to be brought before the federal assembly (Parliament) for approval, only in case the federal council (the executive) or another Canton protests. Thus a Cantonal treaty with a foreign power may go into operation and become a binding contract, without the government of the confederation participating in the arrangement. The Constitution provides, also, that while " official intercourse between the Cantons and foreign governments or their representatives, shall take place through the federal council, nevertheless, the Cantons may correspond directly with the inferior officials and officers of a foreign state in regard to subjects enumerated in the preceding article." 26

The centralizing process has been carried further in Switzerland than in Germany; for the constitution restricts the treatymaking power of the Cantons by express limitations and the right of legation has become a mere power of corresponding with surbordinate foreign officials.

The reasons for these differences between the constitutions of Germany and Switzerland and that of the United States are of course historical. The thirteen original states, during the time that they lived under the Articles of Confederation, never

26. Swiss Constitution (Hart's Translations), Articles 8,9, ro, $82 \S 5$.

Bluntschli classes as treaties those "concluded between the subordinate authorities or different administrative services of two or more states, as to matters relating to the exercise of their functions." Those which enter " partially" into this class, he adds, are those which "have for their object the regulation of frontiers, when this matter is left to provincial governments; judicial requisitions effectuated without the intervention of the supreme authority; reformations of river courses in the provinces; . . . treaties between neighboring communes of two different states, relative to questions of local and communal interest." Droit. Int. $\S 432,2$.

These are manifestly the agreements contemplated by articles 107 and 108 of the Constitution of Argentina, where it is provided that "the Provinces shall have the power to conclude, with the knowledge of the federal Congress, such partial treaties, as may be necessary for the purposes of administrative justice, or for regulating provincial interests, or undertaking public works, \&c." But " they cannot, without authority from the federal Congress, enter into any partial treaties of a political character."

The agreements referred to, in Bluntschli's work and in the Argentine Constitution, as partial treaties, relate to matters of an administrative and judicial character, or are purely local in scope and application. They are con. fessedly treaties of a quasi sort. In the view of the present writer, they ought to be called "agreements" and thus differentiated from engagements between nations, which necessarily belong to the field of foreign policy or international law. 
made individually any treaties with foreign powers. In Germany and Switzerland the component states had for several centuries each enjoyed the right of making treaties and the right of legation. The adoption of more centralized forms of government naturally involved compromises in favor of state independence and the results were those which have been described. The states of the American Union have no standing internationally. As to foreign powers they are mere departments. The sole point at which they can come into official relations with a foreign government is by means of a local and non-political agreement.

The writer does not wish to be understood as supporting the proposition that the states of the American union ought in practice to enter into agreements with foreign powers. Whenever possible the subject should be regulated through action by the general government. Nevertheless, it is the basic principle of federal government that the individual states enjoy an autonomy in matters merely local, not effecting the interests of the state as a whole. May there not properly be an autonomy in local external affairs, at least as to the states bordering on Canada or Mexico, just as there is a local autonomy in matters purely domestic? The constitutional provision, "agreement or compacts with foreign powers" plainly indicates its existence. Constitutional practice in Europe on this subject points to the field in which the members of a federal government may safely be permitted to regulate their external affairs. The provisions of the Swiss constitution limit these agreements to the administration of public property and border and police intercourse. Here is a field, non-political in character, which, if restricted to agreements with immediate foreign neighbors, might, perhaps be left to the states. As has been said, the necessity of subsequent approval by Congress, removes the danger of confederatism.

(To be concluded.) 